\title{
THE EFFECT OF POLITICAL CONNECTION OF CSR DISCLOSURE WITH PROFITABILITY AS MODERATING VARIABLE
}

\author{
Erdayosi $^{1{ }^{1 *}}$ Wika Arsanti Putri ${ }^{2)}$ \\ Program Studi Akuntansi Manajerial, Politeknik Negeri Batam \\ ${ }^{1)}$ E-mail: ochyerda@gmail.com \\ Program Studi Akuntansi Manajerial, Politeknik Negeri Batam \\ ${ }^{2)}$ E-mail: wika@ polibatam.ac.id
}

\begin{abstract}
The purpose of the study is to examine the effect of political connection to the level of voluntary corporate social responsibility disclosure with profitability as a moderating variable. Political connection in this research using 2 proxies that are the government share ownership and the board of directors. The sample of this study was 110 state-owned companies listed on the Indonesia Stock Exchange (IDX) for the period 2012-2017. The sampling method uses purposive sampling technique. The analytical tool used is simple linear regression analysis and analysis of Moderated Regression Analysis (MRA). The results of the study found that political connection of the government ownership and board director doesn't show any significant effect toward CSR disclosure. Profitabilias, as a moderating variable, doesn't moderate the influence of political connection using both proxies toward corporate social responsibility disclosure. The study makes a significant contribution to the literature by examine the influence political connection and CSR using neo-pluralist perspective of legitimacy theory. The implication of this research was suggested to increase the sector and more detail proxy of the research variable.
\end{abstract}

Keywords: political connection; profitability; corporate social responsibility.

\begin{abstract}
Abstrak
Penelitian ini bertujuan untuk menguji pengaruh koneksi politik perusahaan terhadap luas pengungkapan CSR dengan profitabilitas sebagai variabel moderasi. Koneksi politik perusahaan diukur menggunakan 2 proksi yaitu kepemilikan saham pemerintah dan dewan direksi. Profitabilitas perusahaan dihitung menggunakan retun on asset ratio. Sampel penelitian ini adalah 110 perusahaan BUMN yang terdaftar di Bursa Efek Indonesia (BEI) periode 2012-2017. Metode pengambilan sampel menggunakan teknik purposive sampling. Alat analisis yang digunakan adalah analisis regresi linear sederhana serta pengujian Moderated Regression Analysis (MRA). Hasil penelitian menemukan bahwa koneksi politik perusahaan dilihat dari kepemilikan saham pemerintah maupun dewan direksi perusahaan tidak berpengaruh terhadap luas pengungkapan CSR. Profitabilias sebagai varibel moderasi ditemukan tidak memoderasi pengaruh koneksi politik perusahaan terhadap luas pengungkapan CSR baik menggunakan proksi kepemilikan pemerintah maupun dewan direksi. Penelitian ini memberikan kontribusi signifikan terhadap literatur dengan melihat pengaruh koneksi politik di Indonesia terhadap CSR dengan menggunakan pandangan neo-pluralis teori legitimasi. Implikasi dari penelitian ini menyarankan untuk penelitian selanjutnya agar dieksplor pada sektor perusahaan yang lebih luas dengan proksi variabel yang lebih detail.
\end{abstract}

Kata kunci: Koneksi politik; profitabilitas; corporate social responsibility. 


\section{INTRODUCTION}

Corporate social responsibility (CSR) is a thing that continues to grow and become a concern for companies and organizations in the world, one of them is Indonesia. The practice of CSR in Indonesia is regulated in Law No. 40 of 2007 about Perseroan Terbatas article 66 and 74 stated that companies whose business sectors are related to natural resources must implement Corporate Social Responsibility (TJSL). PP No. 47 of 2012 concerning Social and Environmental Responsibilities of Perseroan Terbatas Company, relating to sustainable development. As well as Law No. 25 of 2007 concerning Investment which regulates every investor is obliged to carry out corporate social responsibility. Therefore currently CSR is not merely a matter of voluntary nature, but an obligation even though there are no clear legal sanctions based on the act but there will be consequences from the environment.

Corporate Social Responsibility is a form of corporate care in various fields of life. CSR focuses on understanding the company's commitment to maintaining sustainability by paying attention to harmonious and balanced relationships between values, norms, culture of the local community and the environment. Thus, companies are no longer only oriented towards the achievement of finance or finance (Lindawati \& Puspita, 2015).

The CSR cases that have occurred in Indonesia include misguided questions about CSR and corporate social conflicts related to CSR. CSR misunderstandings occur in the case of the surrounding industrial community who request a number of funds to the company as a form of CSR, if not given then they will carry out activities that hinder the company's operations, the company believes as extortion (Detiknews, 2017). Regarding the social conflict there was an accusation from the Executive Board of Nahdatul Ulama (PBNU) that BUMN employees were supporters of the ideology of the establishment of an Islamic state and antiPancasila. In fact, according to them, the anticriminal group or the so-called pro-khilafah group can easily get funding support from social assistance from state-owned companies or what we know as corporate CSR funds (CNNIndonesia, 2018).

Indonesia is a democratic country with a presidential system. Therefore, political existence in Indonesia is very strong, this is supported by the existence of multi-party systems (Antaranews.com, 2013). Most politicians not only make their activities in the political world a single job, but many of the members are involved in the political parties and state cabinet which also serves as a board of directors in a company. As reported by kompas.com (2015) it is known that during the leadership of the President and Vice President Jokowi-JK it was found that there were 16 Jokowi politicians and volunteers who were commissioners of state-owned companies.

According to BRI's Chosen Director Gatot Mardiwasisto in Financial (2015) said that a politician can occupy the position of commissioner or director in a state-owned bank if he has removed his managerial position in his political party. The problem of multiple positions of BUMN employees violates the rules of Law No. 25 of 2009 Article 17 concerning Public Services. Multiple positions are prohibited because it is feared that it will cause conflict of interest (Tribunnews.com, 2017).

Based on CSR cases as well as the company's political connections that occur in state-owned companies in Indonesia, the researchers are interested in further investigating these issues. Researchers refer to the research of Muttakin, Mihret, \& Khan (2018) which examined the company's political connections and corporate social responsibility disclosures in 396 companies registered in Bangladesh Stock Exchange Dhaka in 2005-2013. This study uses a neo-pluralist hypothesis from legitimacy theory. The results of the study found that the company's political connections negatively affected the level of corporate CSR disclosure. This research is a development of the research of Muttakin, Mihret, \& Khan (2018), the difference lies in: (a) the research period, namely from 2013-2017; (b) the object of research is the state-owned company listed on the Indonesia Stock Exchange (c) the research variable which is adding profitability as a moderating variable.

\section{THEORITICAL REVIEW}

\section{Legitimacy Theory}

According Suchman (1995) Legitimacy is a general perception or assumption that entity actions are desired, appropriate, or appropriate in several systems of norms, values, beliefs, and definitions that are socially constructed. The articulation of the dominant legitimacy theory is based on the concept of "social contract" which is described to provide a basis for identifying the rights given to the company by the community and the expectations of the community that occur in return. From this perspective, the company will have legitimacy to operate if the company's values and actions are consistent with the values and expectations of the community. Such conformity allows the company to accept community acceptance and good corporate image needed for the sustainability of the company's 
existence. This theory states that companies will do CSR because of the impact of social, political and economic pressures from outside.

Guthrie \& Parker (1989) legitimacy theory questions the power of the theory of political economy determines the company's decision to disclose CSR information. company. This is in line with the new point of view regarding the legitimacy theory of the neo-pluralist view. This view argues that the disclosure of voluntary CSR is inversely proportional to the pluralist view which finds that political and business elites can align their interests in CSR disclosure or conflict of interest.

\section{Corporate Political Connection}

According to Gomez \& Jomo (1999) the company is said to have a political connection if the company or its owner (conglomerate) has a close relationship with the government. Close relations here are companies in the form of BUMN or BUMD. The conglomerates (owners) of companies that are said to be closely related to the government are conglomerates or owners who are prominent political figures, namely members of the central government council and / or members of political parties.

According to Faccio (2006) a politically connected company if at least one of the company's major shareholders (anyone who directly or indirectly controls at least $10 \%$ of the votes based on the number of shares held) or the president director (CEO, president, vice president or secretary) is member of parliament, a minister (including the Prime Minister), or Head of State (dictator, president, King or Queen) or "closely related" to a top politician.

According to Fan, Wong, \& Zhang, (2007) the political connection of a director or CEO is seen from whether currently or previously served in the government both the central government and the regional government, as well as the military. The company is defined as having a political connection if one of the company owners, the board of directors or the board of commissioners has served or is currently a government official, military official, or member of parliament during the research period.

\section{Corporate Social Responsibility (CSR)}

(2007) defines CSR as a continuing commitment by the business world to act ethically and contribute to the economic development of the local community or the wider community, along with improving the standard of living of workers and their families. According to Kotler and Lee (2005) consider it as a company's commitment to improve community welfare through good business practices and contribute some of the company's resources.

\section{Profitability}

Profitability is a factor that gives management freedom and flexibility to conduct and disclose social responsibility to shareholders more broadly (Heinze, 1976). The relationship between social responsibility and company profitability is a basic assumption that reflects the view that social reactions require a managerial style. So that the higher the level of profitability of a company, the greater the social information disclosure (Hackston \& Milne, 1996).

\section{Literature}

Research by Muttakin, Mihret, \& Khan, (2018) which examined the company's political connections and CSR disclosures, used neo-pluralist hypotheses and empirical evidence on 936 companies listed on the Dhaka Stock Exchange in 2005-2013. The results show that companies that are politically connected, disclosure of corporate CSR will decrease. This finding supports the neo-pluralist argument that political connections can allow companies to distance stakeholder pressure related to the potential legitimacy threats that come from poor CSR performance.

Rahman \& Ismail, (2016) conducted a study to examine the effect of corporate political connections on social responsibility disclosures in 300 nonfinancial companies listed on Bursa Malaysia in 2013. The company's political connections were separated into 2 categories namely by political connection on the basis of government ownership and the amount politicians on the board of directors (representation of politician on board). The results show that government ownership proxies have a positive effect on CSR disclosure. While for the politician on board proxy there was no significant influence of political connections on the disclosure of corporate CSR.

Research by Huang \& Zhao, (2016) which examined the influence of political connections on CSR in private companies in China. CSR in this research is divided into several proxies, namely community orientation, investor orientation, customer orientation, and government orientation. Find the results as follows: (1) Political connections have a positive effect on the CSR of private companies, (2) The political connections of private companies have a positive effect on community and customer oriented responsibilities, (3) there is no significant difference in the responsibility of investors (4) social 
responsibility oriented to the government and employees is better if the company is politically connected.

Wang, Jin, \& Jie's research, (2015) examined the influence of political connections on corporate social responsibility in 9236 research groups of private companies in 2010 and 2012 in China. Find out that (1) Private companies are more likely to be involved in CESR if their leaders are members of "Two Meeting". (2) Private companies with larger financial sources are more likely to be involved in actions related to CESR. (3) Private companies whose leaders take the position of government as officials tend to participate in CESR-related activities more important than adopting the CESR decoupling strategy.

Sudibyo \& Jianfu (2016) examined political connections, state-owned enterprises and tax avoidance in companies registered in Indonesia in 2007-2013. The results show that politically connected companies pay lower taxes than companies that are not politically connected. This research also examines how state-owned companies are correlating in tax avoidance. And companies that employ independent commissioners who are politically connected in this study are more likely to show tax avoidance behavior.

Butje \& Tjondro (2014) examined the influence of executives and political connections on tax avoidance in 74 non-financial companies listed on the Stock Exchange in 2009-2013. The results showed that executive character and political connections had a significant effect on tax avoidance. Whereas for the control variable of company size, leverage, sales growth and industry sector except industry 7 has a significant effect on tax avoidance.

Edmawati (2012) examined the effect of CSRD on firm value with profitability as a moderating variable in manufacturing companies on the IDX in 20062009. The results of this study indicate that CSR disclosure proved to have a significant positive effect on firm value. Profitability as a moderating variable has a negative effect on the relationship between corporate social responsibility disclosure and company value.

Rosiana, Juliarsa, \& Sari (2013) examined the effect of CSR disclosure on firm value with profitability as a moderating variable for 55 samples of individual companies on the IDX in 2008-2012. The results of the analysis show that CSR disclosure has a positive and significant effect on firm value. Profitability as measured by ROA can strengthen the effect of CSR disclosure on company value.
Based on cases such as multiple positions held by the political elite as commissioners in state-owned companies, it is feared that there will be a conflict of interest given that the political elite has the power to make and implement existing policies. Therefore researchers want to know the effect of political connections on CSR disclosure. Political connections in this study are divided into 2 proxies, namely government share ownership and the connection of the board of directors. Then the following hypothesis is proposed:

H1a: There is an influence of the company's political connections based on government share ownership on CSR disclosure.

$\mathrm{H} 1 \mathrm{~b}$ : There is the influence of a politically connected board of directors on CSR disclosure.

Company profitability is a measure in the percentage used to assess the extent to which a company is able to generate profits at an acceptable level. The higher the profitability of the company, the wider the disclosure of CSR. Likewise, vice versa if the probability of the company is low, the possibility of CSR disclosure will be small. But in this case the author wants to see the impact of the existence of the company's political connections. Therefore researchers want to know whether true profitability can strengthen or weaken CSR disclosure caused by political connections, so the hypothesis is proposed as follows:

H2a: Profitability moderates the company's political connections with the government's share ownership proxies on CSR disclosures.

H2b: Profitability moderates the company's political connections with the board of directors proxy on CSR disclosures

Based on the explanation of the development of the hypothesis above, the research model is as follows:

Figure 1 Research Model

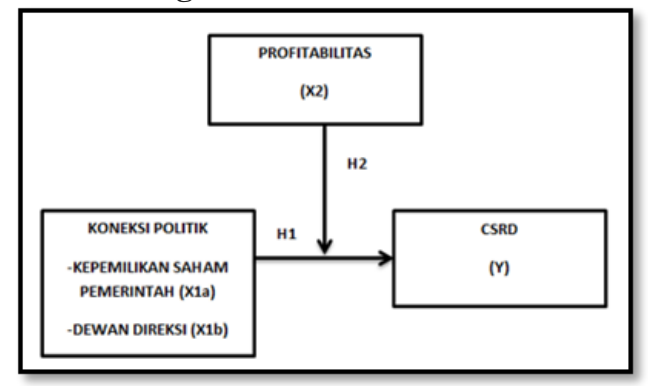

Source: Processed by researchers 


\section{RESEARCH METHODS}

\section{Types of data and research samples}

The type of data used for this study is quantitative data, panel data. The source of research data is secondary data that is using archive data from IDX. This data is obtained from the annual reports of stateowned companies listed on the Indonesia Stock Exchange from 2012-2017. The objects used in this study are state-owned companies listed on the Indonesia Stock Exchange from 2012-2017. The company drawn as a sample is a company that publishes an annual report on web.idx.co.id, a company that contains a report on corporate social responsibility in the annual report, and has complete data related to the variables studied, namely information related to the profile of company directors, percentage composition of holders shares, total assets and company profits. The population in this study is 120 companies. Samples that meet the research criteria are 110 BUMN companies in 20122017.

\section{Operational Definition of Variables}

\section{Dependent Variable Corporate Social Responsibility (CSR)}

Extensive calculation of CSR disclosures follows the research of Muttakin, Mihret, \& Khan (2018) using the index checklist on CSR items. There are 20 CSR items divided into 5 categories. These categories include community, environment, employee, product and service, and value added information. The CSR disclosure index is then derived by calculating the ratio of the actual score given to the maximum score (20) that can be achieved by the company. CSRDI is calculated formula:

$$
\text { CSRDI }=\frac{\text { TOTAL AKTUAL CEKLIS }}{20}
$$

Source: Muttakin, Mihret, \& Khan (2018)

\section{Independent Variables Corporate Political Connection}

Political connections in this study are divided into 2 proxies, namely the proxy of government share ownership and the proxy of the board of directors. Proxy government ownership is calculated through the proportion of government shares owned by the company and the political relations of the company owner (Pranoto \& Widagdo, 2015). Company connections (PLCON) with a board of directors proxy are calculated using a dummy variable, which is given a value of 1 if politically connected, and 0 if not. According to Fan (2007) the criteria for a politically connected board of directors are:

1. A board of directors that holds concurrent positions as a politician affiliated with a political party.

2. The board of directors concurrently serves as a government official.

3. The board of directors concurrently serves as a military official.

4. The board of directors is a former government official or former military official.

\section{Moderation variable Profitability}

Return on assets (ROA) is a form of profitability ratio to measure a company's ability to generate profits, that is by using the company's total assets or existing assets and after deducting capital costs. ROA is calculated using the formula:

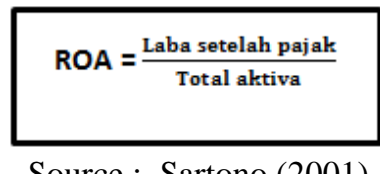

\section{Data analysis technique}

The research data were analyzed using statistical analysis namely simple linear regression and MRA with the SPSS program. The test that will be carried out is the influence test, where it is necessary to find descriptive statistics, correlation and regression tests, but because using parametric statistics, the classical assumption test must be done, namely normality, heterocedasticity and multicollinearity.

\section{Descriptive Statistics Analysis}

According to Ghozali (2006) descriptive statistical testing is carried out with the aim of providing an overview of the data to be tested. Descriptive statistics serve as preliminary information for all research variables, namely to describe in general the characteristics of each variable's data in the sample, the characteristics of the data in question are the mean, median, mode, and standard deviation. So that the data to be tested and analyzed can be normally distributed.

\section{Classic assumption test}

The classic assumption test in this study aims to determine whether the research model used is appropriate. The classical assumption is carried out to fulfill the BLUE (Best Linear Unbiased Estimator) element so that the regression model is not biased 
(Gujarati, 2006). The classic assumption test that will be used by researchers is as follows:

\section{Normality test}

Normality test is a test used to see whether the residual / error value is normally distributed or not, and to find out the regression model which consists of dependent, independent and moderating variables with normal distribution or not. The regression model is said to be good if the data is normally distributed or close (Ghozali, 2009).

In this study the normality test was carried out using one sample kolmogorov-smirnov test, histogram test in graphical form, and normal P plot test. In the one sample test kolmogorov-smirnov variables that have asymp. Sig (2-tailed) below the significance level of 0.05 , it means that the variables have data that is not normally distributed and vice versa (Ghozali, 2009).

\section{Heterocedasticity test}

Heteroscedasticity test is used to see the inequality of the variance of the residual (residual value) one observation to another observation in the regression model. There is no heteroscedasticity is a good regression model (Ghozali, 2009). The presence of heterocedasticity in a linear regression model can be detected by several methods. In this study using the Glesjer test method, namely regression between the independent variables and their residual absolute values. Requirements for regression models that are not exposed to heteroscedasticity are if the value of $t$ count is smaller than the value of $t$ table and the significance value is greater than 0.05 and vice versa.

\section{Multicollinearity Test}

Multicollinearity test is a test that is conducted to determine whether or not there is a correlation between independent variables in the regression model (multiple regression). If there is no correlation between the independent variables, the regression model is good. To find out whether there is multicollinearity or not in the regression model is to look at the value of VIF (Variance Inflation Factor) and tolerance value. Both of these values indicate the size of each independent variable when explained by other independent variables. In the tolerance measure, the decision is if the tolerance value is greater than 0.10 then there is no multicollinearity and vice versa. Whereas in the size of VIF (Variance Inflation Factor), the decision is if the VIF value is smaller than 10.00 then there is no multicollinearity and vice versa.

\section{Regression analysis}

To find out the effect of political connections on the extent of manka CSR disclosures, a simple regression analysis was performed which tested the effect of $\mathrm{X}$ on Y. Meanwhile, to examine the influence of moderating variables using moderated regression analysis (MRA). In more detail are explained as follows:

1. Simple linear regression analysis to test the hypothesis H1a: There is an influence of the company's political connections based on government share ownership of the broad disclosure of corporate CSR.

CSRDI $=\alpha_{1}+\beta_{1} P_{\text {CON }}+\varepsilon_{1}$

Explanation:

$$
\begin{array}{ll}
\text { CSRDI } & =\text { corporate social responsibility index } \\
\alpha_{1} & =\text { constant } \\
\beta_{1} & =\text { regression coefficient } \\
\operatorname{PCON}_{\mathrm{KS}} & =\text { political connection of government } \\
& \quad \text { share ownership } \\
\varepsilon_{1} & =\text { residual }
\end{array}
$$

2. Simple linear regression analysis to test $\mathrm{H} 1 \mathrm{~b}$ hypothesis: There is the influence of a politically connected board of directors on the broad disclosure of corporate CSR.

$$
\operatorname{CSRDI}=\alpha_{2}+\beta_{2} \mathrm{PCON}_{\mathrm{DR}}+\varepsilon_{2}
$$

Keterangan:

CSRDI = corporate social responsibility index

$\alpha_{2} \quad=$ constant

$\beta_{2} \quad=$ regression coeffisient

$\mathrm{PCON}_{\mathrm{DR}}=$ political connection of director's board

$\varepsilon_{2} \quad=$ residual

3. Moderated regression analysis to test hypotheses H2a: Profitability moderates the political connections of companies with the proxy of government share ownership in a broad stage of CSR disclosure.

CSRDI $=\alpha_{1}+\beta_{1}$ PCON $_{K S}+\beta_{3}$ ROA $+\beta_{5}$ PCON $_{K S} *$ ROA $+\varepsilon_{1}$

$\begin{array}{ll}\text { Keterangan: } & \\ \text { CSRDI } & =\text { corporate social responsibility } \\ & \text { disclosure index } \\ & =\text { constant } \\ \alpha & =\text { regression coeffiicient } \\ \beta_{1}, \beta_{3}, \beta_{5} & =\text { political connection of } \\ \text { PCON }_{\mathrm{KS}} & \text { government share ownership } \\ \text { ROA } & =\text { return of asset } \\ \varepsilon & =\text { residual }\end{array}$

4. Moderated regression analysis to test hypotheses $\mathrm{H} 2 \mathrm{~b}$ : Profitability moderates the political connections of companies with the proxy of 
director's board in a broad stage of CSR disclosure.

CSRDI $=\alpha_{2}+\beta_{2}$ PCON $_{D R}+\beta_{4}$ ROA $+\beta_{6}$ PCON $_{\mathrm{KS}} *$ ROA $+\varepsilon_{2}$

$\begin{array}{ll}\text { Keterangan: } & \\ \text { CSRDI } & =\text { corporate social responsibility } \\ & \text { disclosure index } \\ & =\text { constant } \\ \alpha_{2} & =\text { regression coeffisient } \\ \beta_{2}, \beta_{4}, \beta_{6} & =\text { political connection of director's } \\ \text { PCON }_{\mathrm{DR}} & \text { board } \\ \text { ROA } & =\text { return of asset } \\ \varepsilon_{2} & =\text { residual }\end{array}$

\section{Hypothesis testing}

Hypothesis testing is a test used to test the truth of a statistical statement and draw conclusions whether the statement is supported or not supported. The research hypothesis is 2-tailed testing, namely the direction of the hypothesis is not yet known or the direction is not clear (positive or negative). In the hypothesis test it is known that there is a regression test. Regression analysis is used to show the amount of influence between independent variables on the dependent variable. Here are some statistical tests that test researchers will:

\section{Coeffisient of determination $\left(R^{2}\right)$}

The measurement of the coefficient of determination is used to show the effect of the independent variable, namely the company's political connection to the dependent variable change (CSRD) in the form of a percentage. From this it is known how much the dependent variable is able to be explained by its independent variables, while the remainder is influenced by other variables outside the research.

2. Simultaneous Significance (Test F)

The $\mathrm{F}$ test is carried out to test the level of influence of the independent variables on the dependent variable together. The conclusion of the $F$ test is seen from the significance value. If the significance is greater (>) than 0.05 then the null hypothesis is accepted and vice versa.

3. Individual Parameter Significance Test (t Test)

The $t$ test is carried out to test the level of influence of the independent variables on the dependent variable partially. Decisions based on the comparison of $t$ count values for each regression coefficient with $t$ table according to the level of significance used. If the value of $t$ count is greater than $t$ table, then the independent variables individually affect the dependent variable, meaning the hypothesis is accepted. Vice versa, the hypothesis is rejected if the value of $t$ count is smaller than $t$ table.

\section{DISCUSSION}

\section{Descriptive statistics}

The variables described include the extent of CSR disclosure (CSRDI) which is measured by the number of CSR item index checklists divided by the total expected CSR items (20 items). The company's political connection with the proxy of government share ownership (PCON_KS) as measured by the percentage of government share ownership, and the proxy of the company's board of directors (PCON_DD) is measured by dummy variable 1 if politically connected and 0 if not politically connected. Company profitability (ROA). The results of the descriptive statistics of the samples used in this study can be seen in the table as follows

Table 1 Descriptive Statistics

\begin{tabular}{lrrrrr}
\hline Variabel & N & Min & Max & Mean & $\begin{array}{l}\text { Standar } \\
\text { Deviasi }\end{array}$ \\
\hline CSRDI & 110 & 0,25 & 0,85 & 0,584 & 0,174 \\
PCON_KS & 110 & 0,51 & 0,9 & 0,641 & 0,106 \\
ROA & 110 & - & 0,234 & 0,049 & 0,063 \\
\hline \multicolumn{4}{c}{ Source: Data }
\end{tabular}

Source: Data processed with SPSS 20.0

Based on the table above, the broad variable CSR disclosure (CSRDI) of 110 data shows that the minimum value of 0.25 is found in PT Bank Negara Indonesia (Persero) Tbk, PT Bank Mandiri (Persero) Tbk, PT Krakatau Steel (Persero) Tbk, PT Garuda Indonesia (Persero) Tbk in 2012, PT Adhi Karya (Persero) Tbk in 2012-2016 and PT Timah (Persero) Tbk in 2013. The maximum value of the CSRDI variable was 0.85 found at PT Bank Rakyat Indonesia in 2017 and PT Jasa Marga (Persero) Tbk in 2014,2015,2017. The average value and standard deviation of the variables are 0.58364 and 0.174407 , respectively.

Political connection variables with the proxy of government share ownership are known to have a minimum value of 0.510 found at PT Adhi Karya (Persero) Tbk and PT Pembangunan Perumahan (Persero) Tbk in 2012-2017. The maximum value of 0.900 is found in PT Kimia Farma (Persero) Tbk in 2012,2014,2015,2016 and 2017. The mean and standard deviation or variable deviating values are 0.64068 and 0.105957 , respectively.

The research moderation variable calculated by ROA is known to have an average value and standard 
deviation of 0.04907 and 0.062974 , respectively. The minimum value seen from the ROA of -0.119 shows the company with the lowest profitability or the greatest loss rate in the sample is found in PT Garuda Indonesia in 2014. The maximum value of ROA of 0.234 is in PT Perusahaan Gas Negara in 2012 which means having the highest profitability in the data sample.

Table 2 Desktiptif Statistics Dummy Variables

\begin{tabular}{lll}
\hline Keterangan & Frequency & Percent \\
\hline tidak terkoneksi & 91 & 82,7 \\
politik & & 17,3 \\
terkoneksi politik & 19 & 100,0 \\
Total & 110 & \\
\hline
\end{tabular}

Source: Data processed with SPSS 20.0

This study uses 1 dummy variable, that is political connection with the proxy of the company's board of directors, which is measured through a politically connected and politically connected board of directors. The output of frequency in table 4.3 shows that the average BUMN company that is politically connected is $17.3 \%$, the remaining $82.7 \%$ is not politically connected.

\section{Classical Assumption Test Test Results Normality test}

The results of the normality test with the proxy of government share ownership and the board of directors can be seen from the following tables 3 and 4:

Table 3 Test for Normality of Government Share Ownership Proxies

\begin{tabular}{|c|c|c|}
\hline \multicolumn{3}{|c|}{ One-Sample Kolmogorov-Smirnov Test } \\
\hline \multirow[b]{2}{*}{ Model } & \multicolumn{2}{|c|}{ Unstandardized Residual } \\
\hline & $\begin{array}{l}\text { Analisis Regresi } \\
\text { Linear } \\
\text { Sederhana }\end{array}$ & MRA \\
\hline $\mathbf{N}$ & 110 & 110 \\
\hline $\begin{array}{l}\text { Kolmogorov- } \\
\text { Smirnov Z }\end{array}$ & 1,341 & 1,078 \\
\hline $\begin{array}{l}\text { Asymp. Sig. (2- } \\
\text { tailed) }\end{array}$ & 0,055 & 0,195 \\
\hline
\end{tabular}

Source: Data processed with SPSS 20.0

Table 3 shows the Sig. (2 - tailed) in the Kolmogorov-Smirnov One-Sample Test on simple linear regression analysis and MRA, each valued at 0.055 and 0.195 , which is above 0.05. This means that it can be concluded that the data tested is normally distributed.
Table 4 Test for Normality of Directors' Proxies One-Sample Kolmogorov-Smirnov Test

Unstandardized Residual

\begin{tabular}{lll}
\multirow{2}{*}{ Model } & \multicolumn{2}{c}{ Analisis Regresi } \\
\cline { 2 - 3 } & Linear Sederhana & MRA \\
\hline $\mathbf{N}$ & 110 & 110 \\
$\begin{array}{l}\text { Kolmogorov- } \\
\begin{array}{l}\text { Smirnov Z } \\
\text { Asymp. Sig. (2- } \\
\text { tailed) }\end{array}\end{array}$ & 1,320 & 1,031 \\
\hline
\end{tabular}

Source: Data processed with SPSS 20.0

Table 4 shows the Sig. (2 - tailed) in the Kolmogorov-Smirnov One-Sample Test on simple linear regression analysis and MRA valued at 0.061 and 0.238 , respectively, above 0.05 . So it can be concluded that the data tested is normally distributed.

\section{Multicollinearity Test}

The multicollinearity test is carried out by the process of the company's political connections, namely the proxy of government share ownership and the board of directors, each of which can be seen in the following tables 5 and 6:

Table 5 Multicollinearity Test of Government Share Ownership Proxies

\begin{tabular}{lcc}
\hline \multirow{2}{*}{ Model } & $\begin{array}{c}\text { Regresi } \\
\text { Linear }\end{array}$ & MRA \\
\cline { 2 - 3 } & Collinearity & Collinearity \\
& Statistics & Statistics \\
& Tolerance & Tolerance \\
\hline PCON_KS & 1,000 & 0,574 \\
ROA & & 0,025 \\
PCON_KS*ROA & & 0,026 \\
\hline
\end{tabular}

Source: Data processed with SPSS 20.0

From the table above, it can be seen that the multicollinearity test from a simple linear regression analysis of the tolerance value is $1,000>0.10$ indicating that there is no indication of multicollinearity. Whereas for moderation analysis it can be seen that multicollinearity occurs on the independent variables ROA and PCON_KS * ROA where the value of tolerance is $<0.10$. This is due to the testing of the moderating variable with the interaction test having a tendency that there will be high multicollinearity between independent variables which will violate the classic assumption test. To overcome this multicollinearity, a method called the residual test was developed (Ghozali, Multivariete Analysis Application, 2016). The residual test results can be seen in table 6 below. 
Table 6 Residual Test

Coefficients $^{\mathbf{a}}$
\begin{tabular}{|l|l|l|l|l|l|}
\hline Model & \multicolumn{2}{|l|}{$\begin{array}{l}\text { Unstandardized } \\
\text { Coefficients }\end{array}$} & $\begin{array}{l}\text { Standardized } \\
\text { Coefficients }\end{array}$ & t & Sig. \\
\cline { 2 - 5 } & B & $\begin{array}{l}\text { Std. } \\
\text { Error }\end{array}$ & Beta & & \\
\hline $\begin{array}{l}\text { (Constant) } \\
\text { CSRDI }\end{array}$ &, 048 &, 013 & & 3,809 &, 000 \\
,- 001 &, 021 &,- 004 &,- 038 &, 970 \\
\hline
\end{tabular}

a. Dependent Variable: AbsRes_1

Source: Data processed with SPSS 20.0

The moderating variable in this study is ROA, the independent variable is PCON_KS and CSRDI as the dependent variable. The residual test is done by regressing ROA $=\alpha+\beta 1$ PCON_KS $+\varepsilon$, then regression $1 \varepsilon l=\alpha+\beta 1$ CSRDI. ROA is considered a moderating variable if the parameter coefficient value is negative and significant. From table 5 the value of the parameter coefficient is -0.038 which means negative and the significant value is 0.970 .

Table 7 Multicollinearity Test of the Board of Directors

\begin{tabular}{|c|c|c|}
\hline \multirow{3}{*}{ Model } & $\begin{array}{c}\text { Linear } \\
\text { Regression }\end{array}$ & MRA \\
\hline & $\begin{array}{l}\text { Collinearity } \\
\text { Statistics }\end{array}$ & $\begin{array}{c}\text { Collinearity } \\
\text { Statistics }\end{array}$ \\
\hline & Tolerance & Tolerance \\
\hline PCON_DD & 1,000 & 0,510 \\
\hline ROA & & 0,913 \\
\hline PCON_DD $*$ ROA & & 0,492 \\
\hline
\end{tabular}

Source: Data processed with SPSS 20.0

Table 7 shows that all independent variables with tolerance value above 0.10 means that it can be concluded that the research data does not contain symptoms of multicollinearity.

\section{Heteroscedasticity Test}

Table 8 Heteroscedasticity Test of Share Ownership Proxies

\begin{tabular}{lllll}
\hline \multirow{2}{*}{ Model } & \multicolumn{3}{c}{$\begin{array}{c}\text { Linear } \\
\text { Regression }\end{array}$} & MRA \\
\cline { 2 - 5 } & $\mathrm{T}$ & Sig. & T & Sig. \\
\hline PCON_KS & $-0,502$ & 0,617 & $-1,958$ & 0,053 \\
ROA & & & $-1,784$ & 0,077 \\
PCON_KS*ROA & & & 1,586 & 0,116 \\
\hline \multicolumn{4}{c}{ Source: Data processed with SPSS 20.0}
\end{tabular}

The number of samples in this study is 110 data which means the value of $t$ table with $\mathrm{N}=110$ is 1.9818. From the table above, it is known that all $t$ counts are smaller than table and the significance value is greater than 0.05 , which means that the study model has no heterocedasticity.
Table 9 Heteroscedasticity Test of the Proxy of the Board of Directors

\begin{tabular}{lccrc}
\hline \multirow{2}{*}{ Model } & \multicolumn{2}{c}{$\begin{array}{c}\text { Linear } \\
\text { Regression }\end{array}$} & \multicolumn{2}{c}{ MRA } \\
\cline { 2 - 5 } & $\mathrm{T}$ & Sig. & $\mathrm{T}$ & Sig. \\
\hline PCON_DD & 1,226 & 0,223 & 1,642 & 0,103 \\
ROA & & & - & 0,445 \\
& & & 0,766 & - \\
PCON_DD*ROA & & & 1,805 & 0,074 \\
\hline
\end{tabular}

Source: Data processed with SPSS 20.0

The number of samples in this study is 110 data which means the value of t table with $\mathrm{N}=110$ is 1.9818. From the table above, it is known that all $\mathrm{t}$ counts are smaller than $t$ table and the significance value is greater than 0.05 , which means that the study model has no heterocedasticity.

\section{Coefficient of Determination}

Table 10 Coefficient of Determination

\begin{tabular}{cc} 
Model & R Square \\
\hline H1a & 0,001 \\
H1b & 0,006 \\
H2a & 0,023 \\
H2b & 0,028 \\
\hline Source: Data processed with SPSS 20.0
\end{tabular}

In the first model, the coefficient of determination (R2) of 0.001 means that only $0.10 \%$ of the dependent variable, namely the extent of CSR disclosure can be explained by an independent variable, that is political connection with the proxy of government share ownership. While the rest (100\% $0.1 \%=99.9 \%$ ) is influenced by other factors that are not in the model. In the second model, the $\mathrm{R}$ square value is 0.006 . This means that $0.60 \%$ of the dependent variable, which is the extent of CSR disclosure, can be explained by the independent variable, the political connection with the proxy of the board of directors. While the remaining $99.4 \%$ is influenced by other factors that are not generated in the research model. In the third model, the adjusted $\mathrm{R}$ square value is 0.023 . This means that $2.30 \%$ of the dependent variable, which is the extent of CSR disclosure, can be explained by the independent variable namely political connection with the proxy of share ownership and the moderating variable, namely profitability (ROA). While the rest of $97.70 \%$ is influenced by other factors not included in the research model. In the third model, the adjusted $\mathrm{R}$ square value is 0.028 . This means that $2.80 \%$ of the dependent variable, which is the extent of CSR disclosure, can be explained by the independent variable, the political connection with the board of 
directors proxy and the moderating variable, namely profitability (ROA). While the remaining $97.20 \%$ is influenced by other factors not mentioned in the research model

\section{Simultaneous Testing (F)}

Table 11 F Test Results

\begin{tabular}{ccc}
\hline Model & F & Sig. \\
\hline H1a & 0,065 & 0,799 \\
H1b & 0,657 & 0,419 \\
H2a & 0,832 & 0,479 \\
H2b & 1,01 & 0,391 \\
\hline Source: Data processed with SPSS 20.0
\end{tabular}

Based on the results of statistical calculations, it is known that in the first model (H1a) the F-count value is 0.065 with profitability of 0.799 . Because the number of probabilities is far greater than 0.05 , it can be concluded that the fit model (the first regression model cannot be used to predict the extent of CSR disclosure). In the second model (H1b), it is known that obtained F-count of 0.657 with probability numbers of $0.419<0.05$, it can be concluded that the fit model (the first regression model cannot be used to predict the extent of CSR disclosure). For the third model $(\mathrm{H} 2 \mathrm{a})$, the calculated $\mathrm{F}$ value is 0.832 with a probability number of 0.479 . This probability number is far greater than 0.05 or it can be concluded that PCON_KS, ROA, and the interaction between PCON_KS * ROA together have no effect on the significance of the company's disclosure of CSR. The fourth model $(\mathrm{H} 2 \mathrm{~b})$ obtained F-count value of 1.01 with probability numbers of $0.391>0.05$ which means that this model cannot be used to predict SCRD or in other words PCON_DD, ROA, and the interaction between PCON_DD * ROA together- the same does not affect the broad disclosure of corporate CSR.

\section{Hypothesis testing \\ Hypothesis 1a}

Table 12 Hypothesis Test Results 1a (H1a)

\begin{tabular}{ccccc}
\hline Variabel & B & $\begin{array}{c}\text { Standar } \\
\text { Eror }\end{array}$ & $\begin{array}{c}\text { t- } \\
\text { hitung }\end{array}$ & Sig. \\
\hline Konstanta & 0,609 & 0,103 & 5,928 & 0 \\
PCON_KS & $-0,04$ & 0,158 & $-0,255$ & 0,799 \\
\hline \multicolumn{4}{c}{ Source: Data processed with SPSS 20.0 }
\end{tabular}

The results of the statistical test $t$ the first equation model show that the independent variable political connection of government share ownership (PCON_KS) has a significance value of $0.799>0.05$ $(\alpha=5 \%)$ so that hypothesis 1a (H1a) cannot be accepted or not supported. The regression equation can be written as follows:

$$
\text { CSRDI }=0,609-0,040 \mathrm{PCON}_{\mathrm{KS}}
$$

The definition of the regression equation is the area of corporate CSR disclosure of 0.609 will decrease by 0.040 if the political connection variable increases by 1 unit.

\section{Hypothesis 1b}

Table 13 Hypothesis Test Results $1 b$ (H1b)

\begin{tabular}{ccccc}
\hline Variabel & B & $\begin{array}{c}\text { Standar } \\
\text { Eror }\end{array}$ & t-hitung & Sig. \\
\hline Konstanta & 0,59 & 0,018 & 32,042 & 0 \\
PCON_DD & $-0,035$ & 0,043 & $-0,811$ & 0,419 \\
\hline \multicolumn{4}{c}{ Source: Data processed with SPSS 20.0 }
\end{tabular}

The results of the statistical test $t$ model $1 \mathrm{~b}$ show that the independent variable political connection of the board of directors (PCON_DD) has a significance value of $0.419>0.05(\alpha=5 \%)$ so that hypothesis $1 \mathrm{~b}$ (H1b) cannot be accepted or not supported. The regression equation can be written as follows:

$$
\mathrm{CSRDI}=0,590+0,035 \mathrm{PCON}_{\mathrm{DD}}
$$

The definition of the regression equation is the area of corporate CSR disclosure of 0.590 will increase by 0.035 if the political connection variable increases by 1 unit.

\section{Hypothesis 2a}

Table 14 Hypothesis Test Results 2a (H2a)

\begin{tabular}{lcccc}
\hline \multicolumn{1}{c}{ Variabel } & B & $\begin{array}{c}\text { Standar } \\
\text { Eror }\end{array}$ & $\begin{array}{c}\text { t- } \\
\text { hitu } \\
\text { ng }\end{array}$ & Sig. \\
\hline Konstanta & 0,624 & 0,14 & 4,467 & 0 \\
PCON_KS & - & 0,209 & - & 0,676 \\
ROA & 0,087 & 0,419 & \\
PCON_KS*ROA & 2,158 & 2,669 & 0,808 & 0,421 \\
\hline
\end{tabular}

Source: Data processed with SPSS 20.0

The results of the statistical test $\mathrm{t}$ the $\mathrm{H} 2 \mathrm{a}$ equation model show that the interaction variable between political connection and profitability has a significance value of $0.808>0.05$ so that hypothesis $2 \mathrm{a}(\mathrm{H} 2 \mathrm{a})$ is not accepted or not supported. The regression equation can be written as follows:

$$
\begin{aligned}
\mathrm{CSRDI}= & 0,624-0,087 \mathrm{PCON}_{\mathrm{KS}}-0,980 \mathrm{ROA}+ \\
& 2,158 \mathrm{PCON}_{\mathrm{KS}} * \mathrm{ROA}
\end{aligned}
$$

From the above equation it can be interpreted that the constant of 0.624 means that if PCONKS, ROA and 
the interaction between PCONKS and ROA are constant or constant, then the average area of CSR disclosure is 0.624 . The PCONKS regression coefficient is -0.087 , meaning that if a political connection increases by 1 unit, then it will be followed by a decrease in the area of CSR confirmation by 0.087 . The profitability coefficient of ROA is -0.980 means that if ROA increases by 1 unit, it will be followed by a broad decrease in disclosure of CSR by 0.980. Furthermore the PCONKS * ROA coefficient of 2.158 means that if the interaction between political connections and profitability increases by 1 unit, it will be followed by a broad increase in CSR disclosures of 2.158

\section{Hypothesis 2b}

Table 15 Hypothesis Test Results 2b (H2b)

\begin{tabular}{|c|c|c|c|c|}
\hline Variabel & B & $\begin{array}{c}\text { Standar } \\
\text { Eror }\end{array}$ & $\begin{array}{c}\text { t- } \\
\text { hitung }\end{array}$ & Sig. \\
\hline Konstanta & 0,576 & 0,023 & 24,95 & 0 \\
\hline PCON_DD & $\begin{array}{c}- \\
0,066\end{array}$ & 0,06 & $-1,09$ & 0,278 \\
\hline ROA & 0,289 & 0,278 & 1,04 & 0,301 \\
\hline $\begin{array}{l}\text { PCON_DD } \\
\text { *ROA }\end{array}$ & 0,742 & 0,949 & 0,782 & 0,436 \\
\hline
\end{tabular}

The results of statistical tests $\mathrm{t}$ the $\mathrm{H} 2 \mathrm{~b}$ equation model shows that the interaction variable between political connections and profitability has a significance value of $0.808>0.05$ so hypothesis $2 b$ (H2b) is not accepted or not supported. The regression equation can be written as follows:

$$
\begin{aligned}
\mathrm{CSRDI}= & 0,576-0,066 \mathrm{PCON}_{\mathrm{DD}}+0,298 \mathrm{ROA}+ \\
& 0,742 \mathrm{PCON}_{\mathrm{DD}} * \mathrm{ROA}
\end{aligned}
$$

From the above equation can be interpreted that the constant of 0.576 means that if PCONDD, ROA and the interaction between PCONDD and ROA are constant or constant, then the average area of CSR disclosure is 0.576 . PCONDD regression coefficient of -0.066 means that if a political connection increases by 1 unit then it will be followed by a decrease in the area of CSR gazing of 0.066. The profitability coefficient of ROA is 0.298 which means that if the ROA increases by 1 unit, it will be followed by an increase in the area of CSR disclosure of 0.298 . Furthermore, the PCONDD coefficient * ROA of 0.742 means that if the interaction between political connections and profitability increases by 1 unit, it will be followed by an increase in the area of CSR disclosure of 0.742 .

\section{Data analysis}

The following is a summary table of the results of the research hypothesis test:

\begin{tabular}{|c|c|c|c|}
\hline & Hypotheses & Sig & Conclusion \\
\hline H1a: & $\begin{array}{l}\text { There is an } \\
\text { influence of the } \\
\text { company's } \\
\text { political } \\
\text { connections } \\
\text { based on } \\
\text { government } \\
\text { share ownership } \\
\text { of the broad } \\
\text { disclosure of } \\
\text { corporate CSR. }\end{array}$ & 0,799 & Unsupported \\
\hline H1b: & $\begin{array}{l}\text { There is an } \\
\text { influence of the } \\
\text { company's } \\
\text { political } \\
\text { connections } \\
\text { based on the } \\
\text { board of } \\
\text { directors on the } \\
\text { broad disclosure } \\
\text { of corporate } \\
\text { CSR. }\end{array}$ & 0,419 & Unsupported \\
\hline H2a: & $\begin{array}{l}\text { Profitability } \\
\text { moderates the } \\
\text { political } \\
\text { connections of } \\
\text { the company } \\
\text { with the proxy of } \\
\text { government } \\
\text { share ownership } \\
\text { on CSR } \\
\text { disclosures. }\end{array}$ & 0,479 & Unsupported \\
\hline H2b: & $\begin{array}{l}\text { Profitability } \\
\text { moderates the } \\
\text { company's } \\
\text { political } \\
\text { connections with } \\
\text { the board of } \\
\text { directors proxy } \\
\text { on CSR } \\
\text { disclosure }\end{array}$ & 0,391 & Unsupported \\
\hline
\end{tabular}

Table 4.17 Summary of Hypothesis Test Results

Source: Processed by researcher

The Influence of Political Connections of Government Share Ownership on Disclosure of CSR

Based on the results of testing the hypothesis (H1a) shows that there is no significant influence between 
the political connections of government share ownership on the CSR disclosure. This states that the first hypothesis (H1a) is not supported. These results indicate that the level of percentage of different government shareholdings in state-owned companies will not affect the disclosure of CSR. This shows that the state as the owner of the company has very strong control over the company because the voice of other entities or other shareholders is the voice of the minority. So that the company has full power in decision making. This power is the authority of the company to disclose CSR information as desired by the company without excessive spotlight from stakeholders. The difference in results from this study is also due to the different sectors of the industry being tested, and the system of government especially political issues that are different in each country. Indonesian government systems and information systems are open and can be seen by anyone, so the possibility of implementing conflicts of interest is very small.

Based on trends, almost all sample companies revealed that the company's social responsibility is almost the same every year and continues to improve in the following year (uptrend). The results of this study contradict the research of Muttakin, Mihret, \& Khan (2018) who found that the company's political connections had a negative effect on CSR disclosure. The results of this study also contradict the research of Rahman \& Ismail (2016) and research by Huang \& Zhao and Wang, Jin, \& Jie, (2015) who found a political connection to government ownership had a positive effect on CSR disclosure. This research contradicts other studies related to political connections, namely the research of Sudibyo \& Jianfu (2016) and research by Butje \& Tjondro (2014) which found that the company's political connections had an effect on tax avoidance.

\section{The Effect of Political Connections of the Board of Directors on Disclosure CSR}

Based on the results of testing the hypothesis (H1b), it shows that there is no significant influence between the political connections of the board of directors on the CSR disclosure. This states that the first hypothesis (H1b) is not supported. Based on these results, it can be announced that there is no conflict of interest with companies connected to politics in Indonesia that are concentrated in state-owned enterprises, this discusses the neo-plural view of legitimacy theory which will discuss the relationships that link corporate politics and CSR disclosure. These results indicate that the company directors who are politically connected to state-owned companies will not influence the broad disclosure of CSR. This is because directors who are connected politically based on their position in the past and in this study found no directors who doubled the position. While disclosure of information, CSR continues to update every day and there are also institutions that provide or give awards such as the Indonesian CSR Award (ICA). Thus the directors will get motivated updates to provide the best not in accordance with the company's average disclosure in the sector. Another thing that might also be of little importance is a politically connected company.

The results of this study support the research of Rahman \& Ismail (2016) who found that the board that is politically connected in the company has no effect and is not significant towards CSR disclosure. The results of the study contradict the research of Muttakin, Mihret, \& Khan (2018) which found political connections had a negative effect on broad disclosure of CSR. This result is also contrary to the research of Huang \& Zhao, Wang, Jin, \& Jie, (2015) who found that the political connection of government ownership had a positive effect on CSR disclosure. In addition, this study contradicts other studies related to political connections, namely the research of Sudibyo \& Jianfu (2016) and research by Butje \& Tjondro (2014) which found that the political connections of companies affect tax avoidance.

\section{Profitability as a Moderating Variable Moderate the Effect of Political Connections on Government Share Ownership on Disclosure of CSR.}

Based on the results of hypothesis testing (H2a) shows that there is no significant influence between the political connections of government share ownership on the CSR disclosure with profitability as a moderator. This states that the hypothesis $(\mathrm{H} 2 \mathrm{a})$ is not supported. This shows that the high and low profitability of a company as seen from the value of return on assets will not strengthen or weaken the influence of the company's political connections on government ownership of the broad disclosure of CSR. In addition, asset returns are only one measure of company profitability, while there are still other measurement tools such as net profit margin, return on sales ratio, return on capital employed, return on investment and earnings per share of the company. From the existing data, almost all state-owned companies reveal that CSR is almost the same every year. This finding is in line with the opinion of Sonny Keraf (1998) which states that a company is an economic institution whose main goal is to seek profit not a social institution. Because if the wider the items disclosed in CSR, the more funds that will be spent should be spent. However, it is also possible that the company did a little disclosure on CSR items, but the budget spent was very large. Based on the results of the study it is known that the company 
carries out CSR disclosures close to the sector average value.

The results of the study support the study (Purwanto, 2011) which found that the company's profitability did not affect the disclosure of corporate social responsibility. In terms of profitability as a moderation, this finding supports the research of Astiari, Atmadja, \& Darmawan (2014) and Pratama, Hapsari, \& Muslih (2016) who find that profitability does not influence or does not moderate the influence of corporate social responsibility on firm value. However, this study contradicts the research of Rosiana, Juliarsa, \& Sari (2013) and Edmawati (2012) who found profitability to moderate the influence of corporate social responsibility on firm value.

\section{Profitability as a Moderating Variable Moderate the Effects of the Political Connections of the Board of Directors on CSR Disclosures}

Based on the results of hypothesis testing (H2b) shows that there is no significant effect between the political connections of the board of directors on the CSR disclosure with profitability as moderating. This states that the hypothesis (H2b) is not supported. This shows that the high and low profitability of a company as seen from the value of return on assets will not strengthen or weaken the influence of the company's board of directors' connection to the broad disclosure of CSR. This is due to the directors of the company as the executor of the company wanting to focus on the company's goals because the company's management attention will be divided if the company is burdened with many objectives, not all companies have skilled personnel in carrying out social activities

The results of the study support the study (Purwanto, 2011) which found that the company's profitability did not affect the disclosure of corporate social responsibility. In terms of profitability as a moderation, this finding supports the research of Astiari, Atmadja, \& Darmawan (2014) and Pratama, Hapsari, \& Muslih (2016) who find that profitability does not influence or does not moderate the influence of corporate social responsibility on firm value. Contrary to the research of Rosiana, Juliarsa, \& Sari, (2013) who found profitability strengthened the influence of corporate social responsibility on firm value. In line with the results of research Edmawati (2012) who found profitability weakened the influence of corporate social responsibility on company value.

\section{CONCLUSIONS AND SUGGESTIONS}

This study aims to examine the effect of the company's political connections as measured by the percentage of government share ownership and the board of directors who are politically connected to the broad disclosure of CSR with profitability as a moderating variable in state-owned companies in Indonesia. The number of research samples is 110 companies from the 2012-2017 observation year. The results of the study based on hypothesis testing found that state-owned enterprises that are politically connected in Indonesia, both in terms of the percentage of government share ownership and the company's board of directors, were found not to influence the broad disclosure of CSR. Other results found that the profitability of companies calculated by ROA did not moderate the influence of the company's political connections on the extent of CSR disclosure, both seen from the percentage of government share ownership and politically connected directors. So that it can be concluded that the case of political connections and CSR does not have a significant impact in Indonesia, especially for state-owned companies.

\section{Implications}

The implication in this research is for the community, the assumption that companies that are under the scope of the government, namely BUMNs to commit fraud in disclosure of CSR for the interests of certain groups is not proven, this means that the company is still carrying out its duties properly. For companies, this result can be a reference for management to implement and improve CSR programs in the sector. The results of this study are expected to add to the research literature that discusses the company's political connections, profitability and corporate social responsibility.

\section{Limitations and Suggestions}

The limitations in this study lie in the research only carried out on state-owned companies listed on the Indonesia Stock Exchange (IDX). This study calculates the extent of CSR disclosures based on the checklist index which consists of 5 categories and 20 disclosure items. Political connections in this study are divided into 2, namely based on government share ownership seen by the percentage of shares and the board of directors who count using dummy variables. This study only uses profitability, namely ROA as a moderating variable.

Based on the results of the study, the advice that can be given is to expand the corporate sector so that the results of the study not only have implications for the BUMN sector but also have implications for other companies in different sectors. In addition, further researchers are expected to add to the leverage of the 
company's political connections such as looking at the influence of commissioners, audit committees, politically connected corporate executive officers. And adding a broader disclosure of CSR disclosures in more detail regarding the items disclosed. And add research variables such as control variables. Increase the number of years of research.

\section{REFERENCE}

Antaranews.com. (2013, November 18). Multipartai dalam sistem presidensial. Jakarta.

Astiari, N. L., Atmadja, A. T., \& Darmawan, N. A. (2014). Pengaruh Tanggungjawab Sosial terhadap Nilai Perusahaan dengan Profitabilitas sebagai Variabel Moderating. E-Journal S1 Ak Universitas Pendidikan Ganesha.

Baker, M. (2004, February 6). Retrieved from Definitions of corporate social responsibility - What is CSR?: http://mallenbaker.net/article/clearreflection/definitions-of-corporate-socialresponsibility-what-is-csr

Belkaoui, A., \& Philip, G. K. (1989)). Determinants of the Corporate Decision to Disclose Social Information. Accounting, Auditing and Accountability Journal,, 2(1), 36-51.

Butje, S., \& Tjondro, E. (2014). Pengaruh Karakter Eksekutif dan Koneksi Politik Terhadap Tax Avoidance. Tax \& Accounting Review, 4(2).

Chowdhury, F. (2009). Problems of women's participation in Bangladesh politics. The Round Table, 98 ( 404), 555-567.

Detiknews. (2017, Februari 17). Salah Kaprah Soal CSR. Jakarta, Indonesia.

Edmawati, S. D. (2012). Pengungkapan Informasi Tanggung Jawab Sosial Perusahaan dengan Pengaruhnya Terhadap Nilai Perusahaan Dengan Profitabilitas Sebagai Variabel Moderasi. Jurnal Manajemen dan Kewirausahaan, 3(3).

Faccio, M. (2006). Politically Connected Firms. American Economic Association, 96(1), 369-386.
Fan, J. P., Wong, T. J., \& Zhang, T. (2007). Politically connected CEOs, corporate governance, and Post-IPO Performance of China's newly partially privatized firms. Journal of Financial Economics, 330-357.

Finansial. (2015, Maret 20). Sejumlah Politikus Duduki Jabatan Komisaris \& Direksi BUMN. Jakarta. Retrieved from http://finansial.bisnis.com/read/20150320/9 0/413841/sejumlah-politikus-dudukijabatan-komisaris-direksi-bumn

Ghozali, I. (2012). Aplikasi Analisis Multivariate dengan program IBM SPSS 20. Semarang: Universitas Diponegoro.

Ghozali, I. (2016). Aplikasi Analisis Multivariete (VIII ed.). Semarang: Badan Penerbit Universitas Diponegoro.

Gujarati, D. N. (2006). Ekonometrika Dasar. Jakarta: Penerbit Erlangga.

Guthrie, J. E., \& Mathews,, M. R. (1985). Corporate social accounting in Australasia. Research in Corporate Social Performance and Policy, 7, 251-77.

Guthrie, J., \& Parker, L. D. (1989). Corporate social reporting: a rebuttal of legitimacy theory. Accounting and Business Research, 19(76), 343-352.

Hackston, D., \& Milne, J. M. (1996). Some determinants of social and environmental disclosures in New Zealand companies. Accounting, Auditing \& Accountability Journal, 9(1), 77-108.

Heinze, D. C. (1976). Financial correlates of a social involvement measure. . Akron Business and Economic Review.

Indonesia, C. (2018). Wasekjen NU Tuding Kelompok Pro Khilafah Hidup dari CSR BUMN. Jakarta.

Lindawati, A. S., \& Puspita, M. E. (2015). Corporate Social Responsibility: Implikasi Stakeholder dan Legitimacy Gap Dalam Peningkatan Kinerja Perusahaan. Jurnal Akuntansi, 6(1), 1-174. 
Rosiana, G. A., Juliarsa, G., \& Sari, M. M. (2013). Pengaruh Pengungkapan CSR Terhadap Nilai Perusahaan Dengan Profitabilitas Sebagai Variabel Pemoderasi. E-Jurnal Akuntansi Universitas Udayana , 723-738.

Sartono, R. A. (2001). Manajemen Keuangan Teori dan Aplikasi Edisi Keempat. Yogyakarta: BPFE-Yogyakarta.

Sudibyo, Y. A., \& Jianfu, S. (2016). Political Connections, State Owned Enterprise and Tax Avoidance : An Evidence From Indonesia. Corporate Ownership and Control, 13(3).

Suharto, E. (2007). Pekerjaan Sosial di Dunia Industri: Memperkuat Tanggungjawab Sosial Perusahaan. Bandung: Refika Aditama.

Suteja, J., \& Mayasari, A. N. (2017). Is Investment Policy Value-Enhancing through CSR Disclosure? Jurnal Keuangan dan Perbankan, 587-596.

Tjondro, E., Widuri, R., \& Katopo, J. M. (2016). Kualitas Corporate Social Responsibility dan Penghindaran Pajak dengan Kinerja Laba Sebagai Moderator. Jurnal Akuntansi dan Keuangan, 105- 118.

Tribunnews.com. (2017, Mei 4). Ombudsman Sebut 222 Komisaris di BUMN Rangkap Jabatan. Jakarta.

Wang, W., Jin, Z., \& Jie, J. (2015). The Effect of Political Connections on Corporate Environmental Social Responsibility: Large Sample Evidence from China. International Conference on Industrial Electronics and Applications.

Wibisono, Y. (2007). Membedah Konsep dan Aplikasi CSR. Gresik: Fascho Publishing. 